\title{
Localization and pattern of expression of a female specific mRNA in Schistosoma mansoni
}

\author{
Mitermayer G. Reis ${ }^{1}$, Janet Kuhns ${ }^{2}$, Ronald Blanton ${ }^{2}$ and Alan H. Davis ${ }^{2,3}$ \\ ${ }^{1}$ Escola de Medicina e Saude Publica and Centro de Pesquisa Goncalo Moniz in Salvador Bahia, Brazil, ${ }^{2}$ Division of Geographic \\ Medicine, Department of Medicine, ${ }^{3}$ Department of Molecular Biology and Microbiology, Case Western Reserve University and \\ University Hospitals, Cleveland, OH, U.S.A.
}

(Received 10 June 1988; accepted 3 August 1988)

\begin{abstract}
To understand mechanisms involved in sex-specific gene expression in Schistosoma mansoni, a cDNA (fs800) was isolated that hybridized to an 800 nucleotide mRNA present in high levels only in mature female worms. The fs $800 \mathrm{cDNA}$ sequence was characterized by two long open reading frames and central stretches of repeated amino acids. Fs 800 did not share similarities with other known sequences in computer searches. In situ hybridization, however, revealed that the mRNA corresponding to fs800 was found only in female vitelline cells, suggesting that the product of this gene may be involved in the production or function of eggs. Fs 800 is developmentally regulated as expression of this gene is dependent on the maturity of female worms. Furthermore, during in vitro culture, when female worms are known to stop egg production, expression of fs 800 selectively ceased.
\end{abstract}

Key words: Female specific cDNA; In situ hybridization; Gene localization; Gene expression; Vitelline cell

\section{Introduction}

Schistosomiasis is a chronic infection caused by several species of trematode of the genus Schistosoma. The most important pathologic consequence of infection is due to the host's immune reaction to eggs deposited in tissues. Egg production in adult female worms, therefore, is a key element in the development of disease after infection.

Despite the importance of oogenesis in schistosomiasis, regulation of this complex process is not well understood. Some factors controlling egg

Correspondence address: A.H. Davis, Division of Geographic Medicine, Department of Medicine, Case Western Reserve University and University Hospitals, Cleveland, $\mathrm{OH}$ 44106, U.S.A.

Note: Nucleotide sequence data reported in this paper have been submitted to the Gen Bank ${ }^{\mathrm{TM}}$ Data Bank with the accession number J03999.

Abbreviation: SSC, standard saline citrate. production have been characterized such as the requirement of adult male worms for the complete physical and sexual maturity of females [1-3]. The presence of adult males, however, is not sufficient for sexual maturation or for production of viable eggs, since worms raised in culture fail to do either despite heterosexual pairing $[3,4]$. Furthermore, when mature worm pairs are obtained from mice and placed in in vitro culture, there is specific and rapid degeneration of vitelline glands and ovaries [5-7].

Descriptions of molecular events associated with maturation and maintenance of female reproduction organs have principally involved the sequencing and expression of genes coding for eggshell proteins [8-12]. To begin to understand the molecular processes associated with reproduction, we characterized one gene expressed only in adult females of Schistosoma mansoni. Using in situ hybridization and in vitro worm culture we show its localization in vitelline cells of mature worms and the necessity of in vivo conditions for expression. 


\section{Materials and Methods}

Parasites. All $S$. mansoni adult worms were from a Puerto Rican strain maintained in Biomphalaria glabrata in Cf1 mice. The worms were recovered by perfusion as described by Duvall and De Witt [13]. Males and females were separated with fine forceps following perfusion.

In vitro worm culture. Immature and mature female $S$. mansoni worms were cultured with either mature or immature male worms for 10 days in $100 \mathrm{ml}$ RPMI 1640 supplemented with L-glutamine, $0.1 \%$ glucose, $5.0 \times 10^{-5} \mathrm{M} 2$-mercaptoethanol, $20 \%$ heat inactivated fetal calf serum, 100 units $\mathrm{ml}^{-1}$ penicillin, $0.1 \mu \mathrm{g} \mathrm{ml}^{-1}$ streptomycin and approximately $10^{7}$ mouse erythrocytes $\mathrm{ml}^{-1}$. The cultures were maintained at $37^{\circ} \mathrm{C}$ in $5 \%$ $\mathrm{CO}_{2}$ [14] with daily media changes. After 10 days, worms were washed in perfusion solution [15], frozen on dry ice and stored at $-70^{\circ} \mathrm{C}$ until RNA extraction.

Preparation of nucleic acids and sequence analysis. Procedures for DNA and RNA extraction and Southern and Northern blotting were performed as described previously $[16,17]$. Blots were probed with fs 800 or hemoglobinase cDNAs labelled with $\left[\alpha{ }^{32} \mathrm{P}\right] \mathrm{dCTP}$ (ICN Corp.) by nick translation. A 275 bp female-specific cDNA described by Davis et al. [16] was used to isolate a $\lambda \mathrm{gt} 11$ clone containing a 792 bp cDNA (fs 800 ). This cDNA was subsequently cloned into $\mathrm{pBR} 322$ and restriction mapped. Appropriate fragments were cloned into M13 and sequenced by the dideoxy chain termination method [18]. The Microgenie software program (Beckman Instruments) was used to organize and analyze the data.

Preparation of $c R N A$ probes. Fs800 was cloned into the EcoRI site of pBS (Stratagene) and the plasmid was digested with restriction enzyme Ssp1 (New England Biolabs) to terminate transcription after the fs 800 insert. Transcripts labelled with ${ }^{35}$ S-UTP (Dupont New England Nuclear Corp.) were produced using T3 and T7 RNA polymerases as per manufacturer's instructions (Promega Biotec), purified by phenol/chloroform extraction and concentrated by ethanol precipi- tation. Additional unincorporated nucleotides were removed by chromatography on Sephadex G50-80. Sense and anti-sense transcripts were identified by hybridization to RNA dot blots. Use of the T3 polymerase produced anti-sense probes, i.e. complementary to the mRNA.

In situ hybridization. Worms were fixed for $20 \mathrm{~min}$ in $4 \%$ paraformaldehyde in phosphate-buffered saline (Sigma diagnostics) and embedded in paraffin. Five $\mu \mathrm{m}$ sections were placed on polylysine-coated slides, deparaffined, hydrated and then treated with acetic anhydride as described by Hayashi et al. [19]. Acetylated slides were washed briefly in $2 \times \mathrm{SSC}(1 \times \mathrm{SSC}$ is $0.15 \mathrm{M} \mathrm{NaCl}, 0.015$ $\mathrm{M}$ sodium citrate) and dehydrated by immersion through a series of increasing ethanol concentrations. For prehybridization, slides were incubated overnight at $50^{\circ} \mathrm{C}$ in $50 \%$ deionized formamide, $0.6 \mathrm{M} \mathrm{NaCl}, 10 \mathrm{mM}$ Tris- $\mathrm{HCl}$ (pH 7.5), 1 mM EDTA, $0.2 \%$ each of bovine serum albu$\mathrm{min}$, Ficoll, and polyvinyl pyrrolidone, $0.5 \mathrm{mg}$ $\mathrm{ml}^{-1}$ salmon sperm DNA, 2-mercaptoethanol and $0.5 \mathrm{mM}$ unlabelled thio-alpha UTP (New England Nuclear) [20]. For hybridization, sections were incubated as above, but alpha thio UTP was omitted and $5 \times 10^{5} \mathrm{cpm}$ of labelled probe was added. After hybridization, the slides were washed successively in $2 \times \mathrm{SSC}$ for $5 \mathrm{~min}$, at $20^{\circ} \mathrm{C}$, and in $2 \times \mathrm{SSC}, 50 \%$ formamide at $50^{\circ} \mathrm{C}$ for $4 \mathrm{~h}$, and then washed briefly with $2 \times \mathrm{SSC}$. To decrease background they were incubated for $30 \mathrm{~min}$ with $10 \mu \mathrm{g} \mathrm{ml}{ }^{-1} \mathrm{RNase} A$ in $100 \mathrm{mM}$ $\mathrm{NaCl}, 1 \mathrm{mM}$ EDTA, $10 \mathrm{mM}$ Tris- $\mathrm{HCl}(\mathrm{pH} 7.5)$ at $37^{\circ} \mathrm{C}$. After washing in $1 \times \mathrm{SSC}, 50 \%$ formamide at $50^{\circ} \mathrm{C}$ for $6 \mathrm{~h}$, the slides were dehydrated. After dehydration the slides were dipped in NTB-3 emulsion (Eastman Kodak) diluted 1:1 with tap water, dried at room temperature, exposed at $4^{\circ} \mathrm{C}$ for $7-10$ days and processed as per supplier's instructions. After washing for $30 \mathrm{~min}$ in water, they were again dehydrated, stained with hematoxylin-eosin, mounted in Histamount and photographed with either brightfield or darkfield illumination using Kodak technical pan film 2415. 


\section{Results}

cDNA sequence. A cDNA corresponding to a female worm specific mRNA was used to screen a cDNA library in $\lambda$ gt11 amp3 [16]. One clone which contained a 792 bp cDNA (fs800) was characterized. This cDNA was completely sequenced (Fig. 1) and its base composition determined to be $73 \%$ A-T. Fs 800 had 2 long open reading frames and each contained stretches of a single amino acid repeat. Frame 1 contained $(\text { Asn })_{4}$ starting at residue 42 and (Asp) $)_{6}$ at residue 73 . It predicted a protein with $8.4 \% \mathrm{Tyr}$,

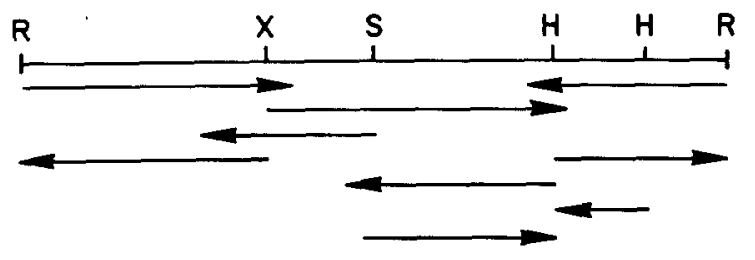

CTIATGAAATACATACATATACTACTIGTATTCATTATATTATCACTATTTATAACAGTT 60 RFl MetLysTyrlleHisileLeuleuvalPheIleIleLeuSerLeupheIleThrVal

ATCAAATCTAATTATTATGATAATAATAATCAAAATCAGAATCAATATTCATATCATCAT 120 RF2

Il LAA SerASnTyrTATGA MetIleIleIleIleLysIlearglleAsnIleHislleIlell

ACTTACAATAATAAIAATCAAGgGACTATCAATCTAAGAATGTCCATAGTGAATCAGAA 180 ThrTyrAsnAsnA snAsnGInGlyAsnTyrGInSerLy SAsnValHisSerGluSerGlu eleuThrl leIleIleIleLysGlyThrI leAsnLeuArgMetSerIleValasnGInAs

CAAAATTCATATAACAAAGAAACAAGGAATAATAATGATGATGATGATGATGATGAAAAT 240 GInAsnSerTyrAsnLysGluThrArgAsnAsnAsnAspAspAspAspAspAspG I uAsn nLys IleHis IleThrLysLysGinglyIleIleMetMetMetMetMetMetMetLys II

ITTGAAAGAAATAAAAAATCTATTCGAICTAGATATCATGGTTATACATATAGgAATGAI 300 PheGl uArgAsnL ys LysSer Il eArgSerArgTyrHisGl yTyrThrTyrArgAsnAsp eLeuLysGlulleLysAsnLeuPheAspLeuAspIl eMetValileHisI leGiyMetII

CMATTCAAICTCGTGGAAATAGTGCAAAAGGTGGCAGTTATTCAGAAAGTACATATITC 360 GInIl eGInSerArgGl yAsnSerAl aL Y SGl yGl y SerTyrSerGl USerThrTyrPhe eLyspheAsnLeuValgiulleValGinLysValAlaValileGinLysValHislleSe

ACATTACATTCTGGAaCAGATAGATATGgTCGACGAAATGATTATTCACGATTTCAAACA 420 ThrLeuH is SerG1 y ThrAspArgTyrG1 yArgArgAsnAspTyrSerArgPheGinThr nHisTyrI leLeugluginIl eAsplitetValAspGIuMet I leIleH isAspPheLysH

CGIGGACGATCCATGGTTATCGTGAAAATATGTITCTIAACGIIITTGATGTAGTTGGA 480 ArgGl yArgSerAsnGly TyrArgGl uAsnMet PheL euAsnVal PheAspValValGly sValAspAspProHetValileVallys 1 leCys PheLeuThrPheLeuMetEnd

MATATIAMACAACACGAAATAAAAGAAAGATAACAAAATCTGAGAAAAATGGTCGTTAC 540 AsnIleLysThrThrArgAsnLysArgLysIleThrLysSerG1uLysAsnGlyArgTyr

ATAMAMAGGATCATATGAATAATAGAGATICTAATACTAACATCAATGAAAAGCCGGAA 600 IleLysLysAspH isMetAsnAsnArgAspSerAsnThrAsnI leAsnGluLys Proglu

IAITCTAAATCACCAGTTTITCAAGGTGGATACAGGTCATTAGAGAAAACTITACTACG 660 TyrSerLysSerProVa]PheGInGlyGI yTyrArgSerLeuGluL ysAsnPheThrThr

MATTATGGAaACTCAaGTAATGCAICAAITCCATTATCCGgTAAACAATCCCAACTAIAG 720 AsnTyrGl yAsnSerSerAsnAl aSer Il eProLeuSerGlyLysGinSerGinLeuEnd

ICAAAACATTATGTAATIAATAATAAATGATATTCGTGTATTCAT(A) 27

Fig. 1. Sequencing strategy and nucleotide sequence of fs800 cDNA. Restriction sites: R, EcoRI; X, XbaI; S, Sall; H, HindIII. The putative polyadenylation signal is underlined.
$15.5 \%$ Asn and $6.3 \%$ Gly. Frame 2 contained $(\text { Ile })_{4}$ starting at residue 2 and (Met) $)_{7}$ at residue 49. The predicted protein in this frame contained $26.3 \%$ Ile, $11.3 \%$ Met, $9.8 \%$ Lys, $0.8 \%$ Tyr and $2.3 \%$ Gly. A typical consensus polyadenylation signal was located 18 bases upstream of the poly(A) tail. Computer searches indicated that neither protein showed significant similarity to known proteins or to other female specific schistosome cDNAs [8-12].

Developmental expression and regulation of fs 800 $m R N A$. Examination of mRNA levels of fs800 at two stages of development was made by Northern blots (Fig. 2A). High level expression of the female specific mRNA was observed only in female worms freshly isolated from mice after 7 weeks of infection. Five-week-old worm pairs and
A

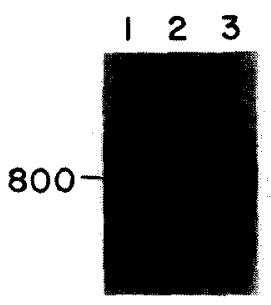

B

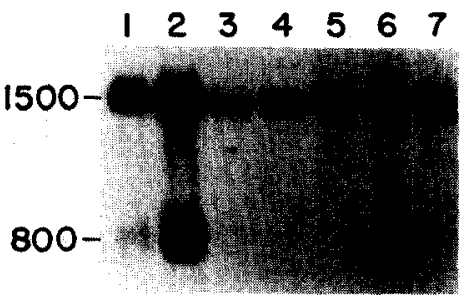

Fig. 2. RNA blot hybridizations: (A) $S$. mansoni mRNA probed with radiolabelled fs 800 . Two $\mu \mathrm{g}$ of poly $(\mathrm{A})^{+}$RNA isolated from worm pairs obtained from mice were subjected to Northern blot and hybridization with fs 800 . Lane 1 , immature worm pairs ( 5 weeks old). Lane 2, mature male worms only ( 7 weeks old). Lane 3 , mature female worms only ( 7 weeks old). The weak hybridization observed to male mRNA likely represented contamination of the preparation of male worms with some females. (B) $S$. mansoni total RNA from worms obtained in vivo and from in vitro cultivated worms. $25 \mu \mathrm{g}$ of total RNA obtained from worms perfused from mice (lanes 1 and 2) or obtained after in vitro culture (lanes 3-7) were subjected to Northern blot hybridization. Blots were probed with fs 800 which hybridized to an 800 nucleotide RNA and then probed with a schistosome hemoglobinase cDNA which hybridized to a 1500 nucleotide RNA. Autoradiographs were overlaid and photographed. Lane 1, RNA from mature male and female worms perfused from mice. Lane 2, RNA from female worms alone. Lane 3 , in vitro cultured mature male and female worms. Lane 4, mature female worms cultured alone in vitro. Lane 5 , in vitro cultured immature female and mature male worms. Lane 6 , in vitro cultured mature female and immature male worms. Lane 7 , mature male worms cultured alone in vitro. 

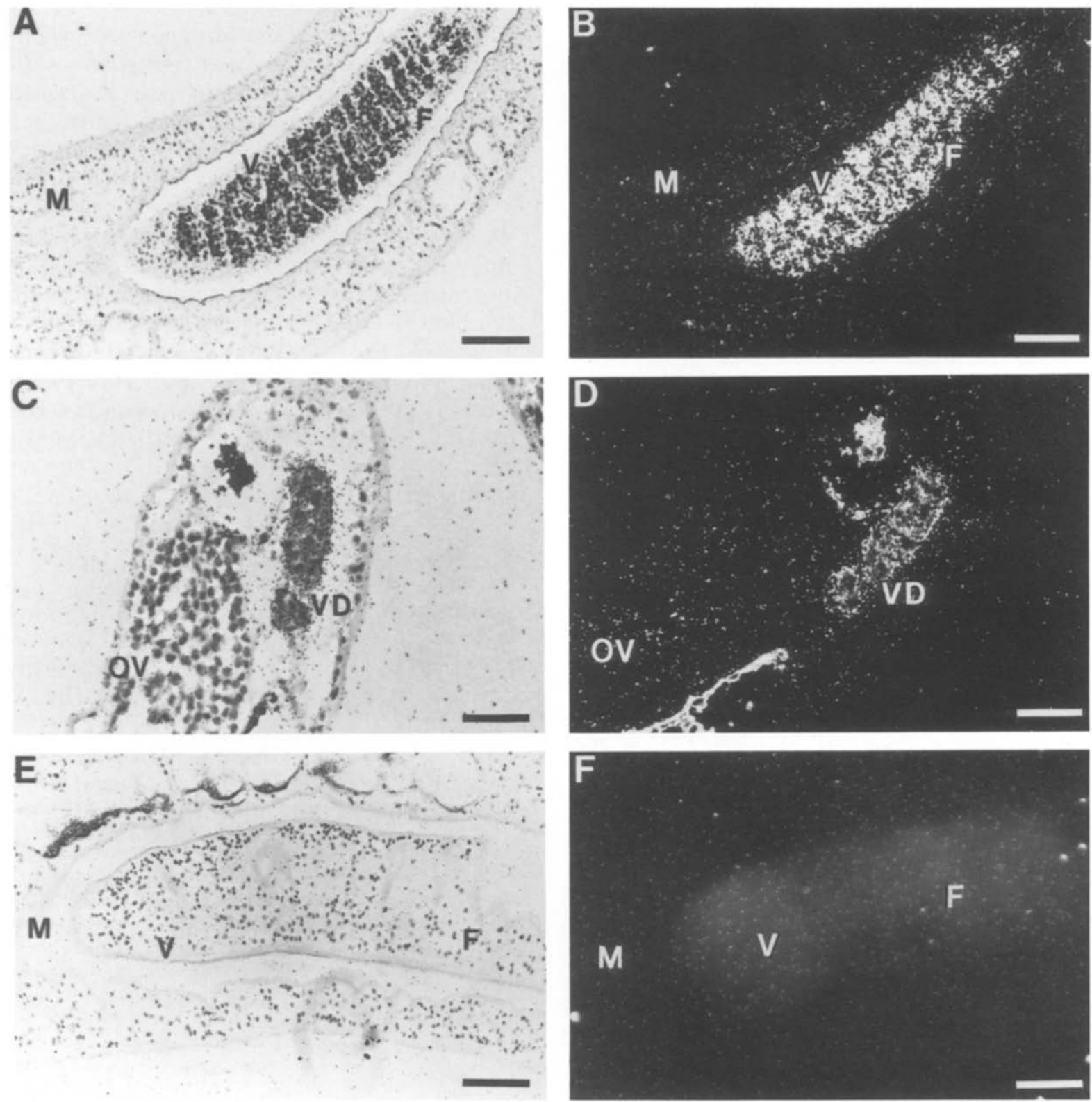

Fig. 3. In situ hybridization of sections of $S$. mansoni worm pairs using an f $800 \mathrm{cRNA}$ probe. The sections demonstrated in panels $A-D$ were probed with the anti-sense $c R N A$ and panels $E$ and $F$ were probed with the sense $c R N A$. In $A, B, E$, and $F$ the bar represents $100 \mu \mathrm{m}$ and in $\mathrm{C}$ and $\mathrm{D}$ the bar represents $50 \mu \mathrm{m}$. (A) An oblique section through $S$. mansoni male (M) and female (F) worms with a female worm situated in the gynecophoric canal of the male. The vitellaria (V) demonstrate their typical pallisade-like structure. (B) The same as panel A, under darkfield illumination to enhance visualization of silver grains. (C) Oblique section through the mid-section of an adult female demonstrating the vitelline duct (VD) and ovary (OV). (D) Same as panel C under darkfield illumination. (E) An oblique section through $S$. mansoni male (M) and female (F) worms probed with the control or sense cRNA probe. (F) Same as panel E under darkfield illumination. 
preparations of mature male worms each exhibited low levels of this specific mRNA. No hybridization was observed in other life cycle stages.

Determinants of fs800 expression were examined in in vitro culture. Immature worms of either sex were co-cultured with mature worms of the opposite sex. Heterosexual culture of worms of the same age was also examined. Specific mRNA expression was again determined by RNA extraction of the cultured worms and Northern blot hybridization. After in vitro culture, expression of fs 800 ceased (Fig. 2B). This was independent of the maturity of the worms or the presence of male worms. To assess whether mRNA production was generally impaired, mRNA from in vitro cultured worms was probed with a cDNA corresponding to the schistosome hemoglobinase [17]. Hemoglobinase mRNA was present in all cultured worms, though slightly decreased relative to levels in worms not placed in culture.

In situ hybridization. To determine the location of the fs 800 mRNA, in situ hybridization was performed using ${ }^{35} \mathrm{~S}$-labelled sense and anti-sense cRNA probes (Fig. 3). Use of the anti-sense cRNA probes showed an accumulation of silver grains over the female vitellaria. Fig. 3A shows an oblique section through $S$. mansoni male and female worms with a female worm situated in the gynecophoric canal of the male. The vitellaria, identified by their typical pallisade-like structure, accumulated a large number of silver grains. Darkfield illumination (Fig. 3B) enhanced visualization of silver grains on the vitelline cells. The male worm was covered with few, diffusely distributed silver grains over the cells at similar levels seen when the sense strand was used for hybridization (Fig. 3E and F). A section through the vitelline ducts and ovary (Fig. 3C and 3D) showed hybridization to vitelline cells within the vitelline duct but not to ovaries.

\section{Discussion}

Egg production in schistosomes is a complex process. Unlike vertebrate development, it requires the production of two different cell types the ovum and the vitelline cells. It also requires the finely co-ordinated movement of each of these cells within the female reproductive system. Each ovum is transported after fertilization to the ootype where it is surrounded by approximately 30 vitelline cells. The vitelline cells provide materials for eggshell formation and may provide nutrients for the developing embryo [21].

The function of several schistosome female specific genes has been inferred from both protein sequence similarity with Bombyx and Drosophila eggshells and similarity to the amino acid composition determined for the schistosome eggshell itself $[8-10,22]$. The proteins predicted by either reading frame of the fs 800 cDNA, however, have no known sequence similarity with any other protein. Furthermore, their predicted amino acid profiles are unlike that determined biochemically for the eggshell. Significantly, the glycine content of most of the putative eggshell proteins is in excess of $35 \%$, whereas fs 800 predicted a maximum glycine content of only $6.3 \%$. DNA sequence comparison of fs 800 with other female specific clones did not demonstrate any direct similarities. There is a striking similarity, however, between the organization of this cDNA and others expressed only in females in that they have two long open reading frames and two series of repeated amino acids. This organization may reflect a common feature of schistosome, femalespecific genes or their products.

Since cDNA sequence data did not reveal aspects of the function of fs 800 , we sought to localize its site of production. In situ hybridization showed that an mRNA for this gene was expressed in mature vitelline cells even as they move into the ootype. This is a step that immediately precedes eggshell formation. Fs 800 , therefore, is likely to have some function in the production or maintenance of the schistosome egg. The findings on in situ hybridization correlated well with the Northern blot analyses that indicated that fs 800 expression reached its highest level only in mature worms, i.e. during egg production. Unlike fs800, putative cDNAs corresponding to the eggshell are abundantly expressed in immature worms [8-10]. Thus, fs 800 may have a function unrelated to eggshell formation and instead be related to other aspects of oogenesis.

In vitro culture of schistosomes has been shown to result in rapid and specific degeneration of vi- 
telline and ovarian cells $[7,23]$. At the molecular level we found that fs 800 was not present in worms maintained in culture for 10 days though the schistosome hemoglobinase was present at a level near that seen in worms freshly isolated from mice. It is possible that mRNAs for some proteins important for egg production are very shortlived, while hemoglobinase is a very long-lived message. The relatively long period of incubation, however, argues against differences in mRNA half lives alone being responsible for lack of fs 800 mRNA accumulation. The sensitivity displayed morphologically by vitelline cells to in vitro culture correlated with the disappearance of the vitelline cell mRNA, fs 800 . The differential sensitivity of cells from this organ to in vitro culture suggests that maintenance of vitelline gene

\section{References}

1 Armstrong, J.C. (1965) Mating behavior and development of schistosomes in the mouse. J. Parasitol. 51, 605-616.

2 Clough, E.R. (1981) Morphology of reproductive organs and oogenesis in bisexual and unisexual transplants of mature Schistosoma mansoni females. J. Parasitol. 67, 535-539.

3 Basch, P.F. (1981) Cultivation of Schistosoma mansoni in vitro. II. Production of infertile eggs by worm pairs cultured from cercariae. J. Parasitol. 67, 186-190.

4 Erasmus, D.A. (1973) A comparative study of the reproductive system of mature, immature and 'unisexual' female Schistosoma mansoni. J. Parasitol. 67, 165-183.

5 Shaw, J.R. and Erasmus, D.A. (1977) Schistosoma mansoni: differential cell death associated with in vitro culture and treatment with Astiban (Roche). Parasitology. 75, 101-109.

6 Popiel, I., Cioli, D. and Erasmus, D.A. (1984) The morphology and reproductive status of female Schistosoma mansoni following separation from male worms. Int. J. Parasitol. 14, 183-190.

7 Irie, Y., Tanaka, M. and Yasuaoka, K. (1987) Degenerative changes in the reproductive organs of female schistosomes during maintenance in vitro. J. Parasitol. 73, 829-835.

8 Bobek, L., Rekosh, D.M., Van Keulen, H. and LoVerde, P.T. (1986) Characterization of a female-specific cDNA derived from a developmentally regulated mRNA in the human blood fluke Schistosoma mansoni. Proc. Natl. Acad. Sci. USA 83, 5544-5548.

9 Simpson, A.J.A., Chaudri, M., Knight, M., Kelly, C., Rumjanek, F., Martin, S. and Smithers, R. (1987) Characterisation of the structure and expression of the gene encoding a major female specific polypeptide of Schistosoma mansoni. Mol. Biochem. Parasitol. 22, 169-176. expression and the integrity of the vitellaria requires host factors absent from in vitro culture systems.

\section{Acknowledgments}

The authors gratefully acknowledge Dr. Ruth Siegel and Jane Petschek for their advice on in situ hybridization. We would also like to thank Eliana Reis, Pierre Peters and Earlene Moss for their excellent technical assistance and Dr. Adel Mahmoud for his critical reading of the manuscript. This work was supported by a Rockefeller Foundation post doctoral fellowship grant, NIH Physician Scientist Award AI 00608, the John D. and Catherine T. MacArthur Foundation and NIH contract AI 15351.

10 Johnson, K.S., Taylor, D.W. and Cordingley, J.S. (1987) Possible eggshell protein gene from Schistosoma mansoni. Mol. Biochem. Parasitol. 22, 89-100.

11 Kunz, W., Opatz, K., Finken, M. and Symmons, P. (1987) Sequences of two genomic fragments containing an identical coding region for a putative eggshell precursor protein of Schistosoma mansoni. Nucleic Acids Res. 15, 5894.

12 Bobek, L.A., Rekosh, D.M. and LoVerde, P.T. (1988) A small gene family encoding an eggshell (chorion protein) of the human parasite Schistosoma mansoni. Mol. Cell. Biol. 8, 3008-3016.

13 Duvall, R.H. and DeWitt, W.B. (1967) An improved perfusion technique for recovering adult schistosomes from laboratory animals. Am. J. Trop. Med. Hyg. 16, 483-486.

14 Doughty, L.B. and Phillips, M. (1982) Delayed hypersensitivity granuloma formation around Schistosoma mansoni eggs in vitro I. Definition of the model. J. Immunol. 128 , $30-36$.

15 Weller, T.H. and Wheeldon, S.K. (1982) The cultivation in vitro of cells derived from adult Schistosoma mansoni $\mathrm{I}$. Methodology: Criteria for evaluation of cultures and development of media. Am. J. Trop. Med. Hyg. 3, 335-348.

16 Davis, A.H., Blanton, R., Rottman, R., Maurer, R. and Mahmoud, A. (1986) Isolation of cDNA clones for differentially expressed genes of the human parasite Schistosoma mansoni. Proc. Natl. Acad. Sci. USA 83, 5534-5538.

17 Davis, A.H., Nanduri, J. and Watson, D.C. (1987) Cloning and gene expression of Schistosoma mansoni protease. J. Biol. Chem. 262, 12851-12856.

18 Sanger, F., Nicklen, S. and Coulson, A.R. (1977) DNA sequencing with chain terminating inhibitors. Proc. Natl. Acad. Sci. USA 74, 5463-5467.

19 Hayashi, S., Gillan, I.C., Delaney, A.D. and Tener, G.M. (1978) Acetylation of chromosome squashes of Droso- 
phila melanogaster decreases the background in autoradiographs from hybridization with ${ }^{125}$ I-labeled RNA. J. Histochem. Cytochem. 26, 677-679.

20 Bandtlow, C.E., Heumann, R., Schwab, M.E. and Thoenen, $H$. (1987) Cellular localization of nerve growth factor synthesis by in situ hybridization. EMBO J. 6, 891-899.

21 Smyth, J.D. and Halton, D.W. (1983) The Physiology of Trematodes, 2nd edn., pp. 86-144, Cambridge University Press, Cambridge.
22 Byram, J.E. and Senft, A.W. (1979) Structure of the schistosome eggshell: amino acid analysis and incorporation of labelled amino acids. Am. J. Trop. Med. Hyg. 28, 539-547.

23 Erasmus, D.A. and Popiel, I. (1980) Schistosoma mansoni: Drug induced changes in the cell population of the vitelline gland. Exp. Parasitol. 50, 171-177. 